\title{
Peningkatan Kualitas Ampas Kelapa melalui Fermentasi dengan Suplemen Organik Cair sebagai Pakan Ayam Kampung
}

\section{Improving the Quality of Coconut Dregs Fermentation with Liquid Organic Supplements as Native Chicken Feed}

\author{
Nurtania Sudarmi, Aswandi, Mofu B \\ Politeknik Pembangunan Pertanian Manokwari, Jl. SPMA Reremi Kotak Pos 143 Kelurahan \\ Manokwari Barat, Manokwari-Papua Barat 98312 \\ nurtania@pertanian.go.id
}

\begin{abstract}
Agricultural people are responsible for providing food, such as meat, eggs and milk. In providing meat, especially chicken, the cost of feed becomes an obstacle for breeders. The local wisdom of plants in Papua is an opportunity to create quality local feed. Utilization of dregs can be used as an alternative ration. The low nutrient content contained in coconut dregs requires a touch of technology to optimize coconut dregs into quality feed. The fermentation process can be a solution to these problems. The experiment used a completely randomized design (CRD) with three treatments and 6 replications. $\mathrm{RO}=100 \%$ Basal Feed (BF); R1 = BF $80 \%$ + Fermented Coconut Dregs 20\%; R2 = BF 60\% + Fermented Coconut Dregs 40\%. The implementation stages consisted of (1) coconut dregs fermentation stage and (2) In-Vivo test on native chickens with the observed variables: feed consumption, body weight gain and feed conversion. The results showed that fermented coconut dregs could be given as starter phase native chicken feed without disturbing the metabolic process. The average provision of coconut dregs as native chicken feed with variable feed consumption, average daily gain (ADG), and FCR had no significant effect ( $P>0.05)$. This means that the addition of fermented coconut dregs up to $40 \%$ has not had a significant effect on ration consumption, ADG, and FCR, so further studies are needed.
\end{abstract}

Keywords: Chicken, Coconut Dregs, Consumption, ADG, FCR

\section{PENDAHULUAN}

Arahan Menteri Pertanian Republik Indonesia, Syahrul Yasin Limpo, untuk menjaga stok pangan bagi 267 jiwa masyarakat Indonesia, menjadi tanggung jawab besar seluruh insan pertanian. Khususnya di masa pandemi Covid-19, menjaga imunitas sangatlah penting dalam upaya tertularnya penyakit yang masih dicari obatnya ini.

Sebagai insan pertanian, khususnya bidang peternakan, sudah bertanggung jawab dalam menyediakan pangan, seperti daging, telur, dan susu. Dalam penyediakan daging, terutama daging ayam, besarnya biaya 
pakan menjadi kendala bagi peternak. Terlebiih saat lock down, peternak di Papua Barat sulit memperoleh pakan berkualitas yang masih mengandalkan pengiriman dari Papua.

Namun demikian, kayanya kearifan lokal tanaman di Papua menjadi peluang untuk menciptakan pakan lokal berkualitas. Pemanfaatan ampas kelapa yang biasanya dibuang oleh masyarakat dapat dijadikan salah satu alternatif ransum. Mengingat masyarakat di Manokwari, Papua Barat menjadi salah satu sentra menghasil minyak kelapa. Sehingga ampas kelapa di Manokwari berpotensi untuk dijadikan pakan ayam kampung.

Ramdani et al. (2016) menyebutkan ampas kelapa mengandung Bahan Kering (BK), Protein Kasar (PK), Lemak Kasar (LK), Serat Kasar (SK), dan Abu berturut-turut $87,10 \%, 3,95 \%, 26,19 \%, 12,92 \%$, dan 1,61\%. Rendahnya kandungan nutrien yang terkandung dalam ampas kelapa membutuhkan sentuhan teknologi untuk mengoptimalkan ampas kelapa menjadi pakan berkualitas. Proses fermentasi dapat menjadi solusi permasalahan tersebut.

Mikroorganisme yang ada mampu mendegradasi serta yang terdapat dalam ampas kelapa menjadi karbohidrat sederhana yang mampu dicerna oleh enzim-enzim dalam saluran pencernaan. Penelitian terdahulu menyebutkan pemanfaatan $40 \%$ ampas kelapa tidak mempegaruhi presentasi karkas ayam kampung (Ramdani et al., 2016). Berdasarkan hal tersebut, maka perlu kajian lebih lanjut terkait peningkatan kualitas ampas kelapa melalui fermentasi dengan suplemen organik cair sebagai pakan ayam kampung.

\section{MATERI DAN METODE}

Penelitian telah dilaksanakan pada bulan Mei hingga Juni 2020, bertempat di Kampus Politeknik Pembangunan Pertanian, Manokwari dengan metode eksperimental. Alat yang digunakan selama penelitian meliputi: (a) Peralatan Fermentasi Pakan, (b) Peralatan pengukutan performan ayam. Sedangkan bahan penelitian yang digunakan: (a) Ayam Kampung fase starter, (b) Suplemen Organik Cair, (c) bahan pakan berupa dedak dan ampas kelapa.

Percobaan menggunakan Rancangan Acak Lengkap (RAL) dengan tiga perlakuan dan 6 ulangan.

R0 $=$ Pakan Basal (PB) 100\%

R1 $=$ PB $80 \%+$ Ampas Kelapa Fermentasi $20 \%$

R2 = PB 60\% + Ampas Kelapa Fermentasi 40\%

Analisis data menggunakan sidik ragam, dan uji lanjut mengunakan Duncan Multiple Range Test (DMRT).

Tata urutan kegiatan ini dengan dua tahapan pelaksanaan yang terdiri dari (1) Tahap fermentasi ampas kelapa dan (2) Uji In-Vivo pada Ayam Kampung dengan peubah yang diamati: Konsumsi Pakan, Pertambahan Bobot Badan dan Konversi Pakan. 


\section{HASIL PENELITIAN}

Kandungan ampas kelapa terdiri dari Bahan Kering (BK), Protein Kasar (PK), Lemak Kasar (LK), Serat Kasar (SK), dan Abu berturut-turut 87,10\%, 3,95\%, 26,19\%, 12,92\%, dan 1,61\% (Ramdani et al., 2016). Sedangkan menurut Amalia D. N. (2018) menyebutkan ampas kelapa memiliki kandungan nutrien sebagai berikut : BK $84,43 \%$, BO 33,88\%, PK 5,63\%, LK 44,70\%, dan SK 15,78\%. Hasil kajian Amanlia D. N. (2018) diketahui dengan penambahan Rhizopus oligoporus sebesar 0,6\% mampu mengoptimalkan kandugan nutrisi dari ampas kelapa dengan rincian : BK $91,02 \%, \mathrm{BO}$ $59,11 \%$, PK 6,08\%, LK $37,93 \%$, dan SK $15,31 \%$.

Hasil penelitian menunjukkan ampas kelapa fermentasi dapat diberikan sebagai pakan ayam kampung fase starter tanpa menggangu proses metabolisme yang dibuktikan dalam Tabel 1.

Tabel 1. Rataan Pemberian Ampas Kelapa sebagai Pakan Ayam Kampung

\begin{tabular}{lccc}
\hline \multicolumn{1}{c}{ Peubah } & \multicolumn{3}{c}{ Perlakuan } \\
\cline { 2 - 4 } & $\mathrm{R}_{0}$ & $\mathrm{R}_{1}$ & $\mathrm{R}_{2}$ \\
\hline $\begin{array}{l}\text { Konsumsi Pakan } \\
\text { (gram/ekor) }\end{array}$ & 30,79 & 29,57 & 27,77 \\
PBB & 5,17 & 5,52 & 4,97 \\
$\begin{array}{l}\text { (gram/ekor/minggu) } \\
\text { Konversi Pakan }\end{array}$ & 5,71 & 5,41 & 5,19 \\
\hline
\end{tabular}

Rataan pemberian ampas kelapa sebagai pakan ayam kampung dengan pubah komsumsi pakan, Pertambahan Bobot Badan (PBB), dan Konversi Pakan tidak berpengaruh nyata $(P>0,05)$. Hal ini berarti penambahan fermentasi ampas kelapa hingga 40\% belum memberikan pengaruh nyata pada konsumsi ransum. Tabel 1. Memperlihatkan rataan konsumsi pakan yang menurun meski tidak berpengaruh nyata $(P>0,05)$. Diduga penurunan tersebut disebabkan oleh palatabilas dari ransum perlakuan. Sejalan dengan hasil penelitian Pakaya et al. (2019) yang mengalami penurunan konsumsi pakan, palatabilas ransum perlakuan dipengaruhi oleh bentuk, rasa, dan suhu ransum.

Penurunan yang terjadi pada konsumsi pakan tidak diikuti dengan PBB ternak. Rataan menunjukkan peningkatan pada R1 dan kembali menurun pada R2. Fahrudin (2016) menyatakan rendahnya PBB pada ayam kampung fase starter dikarenakan kurang terpenuhinya kebutuhan nutrisi yang mengakibatkan terhambatnya laju pertumbuhan. Berdasarkan hasil penelitian Amalia D. N. (2018) ampas kelapa PK $5,63 \%$ meski telah diberi penambahan Rhizopus oligoporus sebesar $0,6 \%$ hanya memberi peningkatan PK 6,08\%. Namun demikian, dari hasil penelitian ini diketahui pemberian ampas kelapa fermentasi hingga $40 \%$ dapat digunakan tetapi belum mampu meningkatakan bobot badan ayam kampung.

FCR juga dapat dipengaruhi oleh kandungan nutrien pada pakan. Konversi pakan yang berkisar 5,71 hingga 5,19 masih tergolong normal. Resnawati (2012) memperoleh konversi pakan yng semula 6,6 menjadi 4,2. Dalam penelitian tersebut dilakukan pada ayam kampung umur 0-6 minggu yang sama dengan umur sampel percobaan ini. Pemberian hingga 40\% ampas kelapa fermentasi pada percobaan belum memberikan pengaruh nyata pada konversi pakan. Tetapi dapat memberi 
gambaran, hingga taraf tersebut ampas kelapa mampu menghasilkan konversi pakan dalam kisaran normal.

\section{KESIMPULAN}

Rataan pemberian ampas kelapa sebagai pakan ayam kampung dengan pubah komsumsi pakan, Pertambahan Bobot Badan (PBB), dan Konversi Pakan tidak berpengaruh nyata $(P>0,05)$. Hal ini berarti penambahan fermentasi ampas kelapa hingga $40 \%$ belum memberikan pengaruh nyata pada konsumsi ransum, PBB, dan Konversi Pakan, sehingga diperlukan kajian lebih lanjut.

\section{DAFTAR PUSTAKA}

Amalia, D. N. 2018. Pengaruh Fermentasi Ampas Kelapa (Cocos nucifer L.) menguunakan Rhizopus Oligoporus terhadap $\mathrm{pH}$ dan Kandungan Nutrien. Sarjana Thesis. Universitas Brawijaya, Malang.

Fahrudin, A., Tanwiriah, W., dan Indrijani, H. 2016. Konsumsi Ransum, Pertambahan Bobot Badan dan Konversi Ransum Ayam Lokal di Jimmy's Farm Cipanas Kabupaten Cianjur. Jurnal IImu Peternakan Universitas Padjajaran: 1-9.

Pakaya, S. A., Zainudin, S., dan Dako, S. 2019. Performa Ayam Kampung Super yang diberi Level Penambahan Tepung Kulit Kakao (Theobroma cacao, L.) Fermantasi dalm Ransum. Jambura Journal of Animal Science Volume 1 No. 2: 40-45.

Ramdani, I., Kardaya, D., dan Anggraeni. 2016. Pengaruh Substitusi Pakan Komersil dengan Tepung Ampas Kelapa terhadap Bobot Potong dan Bobot Karkas Ayam Kampung. Jambura Peternakan Nusantara 2(1): 916.

Resnawati, H. 2012. Inovasi Teknologi Pemanfaatan Bahan Pakan Lokal Mendukung Pengembangan Industri Ayam Kampung. Jurnal Pengembangan Inovasi Pertanian 5 (2) : 79-95. 